MIKOŁAJ MALINOWSKI

Lund University

\title{
ZMIERZYĆ ZACOFANIE. ZESTAWIENIE NAJWAŻNIEJSZYCH SZACUNKÓW MATERIALNYCH STANDARDÓW ŻYCIA W POLSCE PRZEDPRZEMYSŁOWEJ
}

Zarys treści: Celem artykułu jest przedstawienie obecnego stanu wiedzy na temat materialnych standardów życia w Polsce przedrozbiorowej na tle innych państw europejskich, w szczególności w porównaniu z Anglią i Holandią. Tekst ten opisuje istniejace szacunki płac realnych i produktu krajowego brutto per capita dla dawnej Polski oraz wyjaśnia, w miarę możliwości, różnice pomiędzy tymi szacunkami.

The content outline: The purpose of the article is to present a current knowledge of material standards of life in the pre-partition Poland against the backdrop of other European countries, especially in comparison with England and Holland. The text describes the existing estimates of real wages and gross domestic product per capita for old Poland and explains, as far as possible, differences between these estimates.

Słowa kluczowe: Little Divergence, Great Divergence, PKB per capita, płace realne

Keywords: Little Divergence, Great Divergence, GDP per capita, real wages

\section{Wstęp}

Ekonomiści i współpracujący z nimi historycy gospodarczy od dawna próbuja odpowiedzieć na szereg podstawowych pytań związanych z przyczynami rozwoju gospodarczego. Zastanawiaja się, dlaczego niektóre kraje bogaca się, podczas gdy inne pozostają biedne? Jakie sa przyczyny obecnego zróżnicowania w przeciętnych dochodach mieszkańców różnych państw świata? Punktem wyjścia tych rozważań jest 
ustalenie, kiedy dokładnie kraje położone w rejonie Morza Północnego, w szczególności Anglia i Holandia, które jako pierwsze weszły w fazę industrializacji, zaczęły rozwijać się prędzej niż państwa położone w jakimkolwiek innym rejonie Europy albo nawet świata.

Dyskusje nad historycznymi i międzynarodowymi nierównościami w dochodach oparte są głównie na badaniach porównawczych materialnych standardów życia w różnych krajach i prowadzone są wysiłkiem wielu grup badawczych. Celem tego artykułu jest przedstawienie obecnego stanu wiedzy na temat materialnych standardów życia w Polsce przedrozbiorowej na tle innych państw europejskich, w szczególności w porównaniu z Anglią i Holandią.

Międzynarodowy wysiłek badawczy nad chronologia i ustaleniem przyczyn rozejścia się dróg rozwojowych Anglii i Holandii oraz innych krajów Europy albo nawet świata określa się w międzynarodowej i anglojęzycznej literaturze tematu jako Divergence Debate, a więc dyskusją o rozwidleniu. Jeżeli mowa o nierównościach wewnątrz kontynentu europejskiego, używa się określenia Little Divergence (mała dywergencja), jeżeli zaś analizuje się różnice między Europa a innymi kontynentami, mówi się o tzw. Great Divergence (wielka dywergencja). Materialne standardy życia, mierzone za pomoca płac realnych i dochodu narodowego brutto per capita, sa jedynie jednym z wielu wyznaczników rozwoju gospodarczego i cywilizacyjnego, jakie sa przedmiotem badań historycznych. Przykładowo, historycy gospodarczy rekonstruuja również szacunki tzw. biologicznych standardów życia poprzez badania nad wysokością ciała oraz przeciętnej długości życia ${ }^{1}$.

Little Divergence Debate w szczególności skupia się na epoce przedprzemysłowej. Wypracowane $\mathrm{w}$ latach sześćdziesiątych i siedemdziesiątych XX w. tradycyjne stanowisko historyków gospodarczych mówiące, że materialne standardy życia w gospodarkach przedprzemysłowych, ze względu na domniemaną dominującą rolę mechanizmów maltuzjanskich, oscylowały wokół pewnego niskiego poziomu równowagi i że trwały wzrost gospodarczy miał się rozpocząc dopiero wraz z rewolucja przemysłowa, upadło pod wpływem badań empirycznych prowadzonych sukcesywnie od lat osiemdziesiątych ${ }^{2}$. Według

${ }^{1}$ N. Koepke, J. Baten, The biological standard of living in Europe during the last two millennia, EREH, t. 9, 2005, nr 1, s. 61-95; Więcej o tym w tekście Michała Kopczyńskiego w niniejszym tomie.

${ }^{2}$ W. Abel, Agricultural fluctuations in Europe. From the thirteenth to twentieth centuries, London-New York 1980; J.L. van Zanden, 'The Revolt of Early Modernists' and the 'first modern economy': an assessment, EHR, t. 55, 2002, nr 4, s. 619-641. 
szacunków dochodu krajowego brutto per capita oraz płac realnych opracowanych dla szeregu państw zachodnioeuropejskich, już w epoce przedprzemysłowej miały miejsce długie okresy trwałego wzrostu gospodarczego. Sugeruje to, że niektóre społeczeństwa zachodnioeuropejskie mogły uwolnić się od mechanizmów maltuzjańskich. Co więcej, według obecnych ustaleń, pod koniec epoki nowożytnej, to jest około roku 1800, materialne standardy życia w Anglii i Holandii były znaczne wyższe niż w innych krajach europejskich ${ }^{3}$. Oznacza to, że rozejście się dróg rozwojowych różnych krajów znajdujących się na kontynencie europejskim musiało nastapić przed rewolucja przemysłowa. Debata nad mała dywergencją skupia się zatem na ustaleniu, kiedy dokładnie doszło do owego rozwarstwienia gospodarczego wewnątrz kontynentu europejskiego. Dotychczasowe badania porównawcze skupiły się na zestawieniu krajów położonych w basenie Morza Północnego, często uznawanych za jeden rejon gospodarczy, z krajami położonymi nad Morzem Śródziemnym (głównie Hiszpania i Włochami $)^{4}$. W trakcie tych badań dotychczasowa klasyczną interpretację maltuzjańską zastapiły trzy główne hipotezy dotyczące chronologii początków niezaprzeczalnie wyższych materialnych standardów życia w Anglii i Holandii. Po pierwsze, według Şevketa Pamuka, który badał płace realne w ośrodkach miejskich ulokowanych głównie w Europie Zachodniej, trwałe rozwarstwienie dochodowe rozpoczęło się po tzw. czarnej śmierci, która miała miejsce w połowie XIV w. ${ }^{5}$ Według tego autora szok demograficzny miał nie tylko wpłynąc dodatnio na krótkotrwała poprawę materialnych standardów życia, ale także miał pozytywnie przekształcić instytucje ekonomiczne regulujące aktywności gospodarcze w rejonie Morza Północnego i tym samym ukierunkować Anglię i Holandię w stronę trwałego wzrostu gospodarczego. Po drugie, według badań nad płacami realnymi przeprowadzonych przez Roberta Allena, materialne standardy życia w miastach położonych w Holandii i Anglii były wyższe już na początku

${ }^{3}$ J. Bolt, J.L. van Zanden, The 'Maddison Project': collaborative research on historical national accounts, EHR, t. 67, 2014, nr 3, s. 627-651; S. Broadberry, Accounting for the great divergence, „Economic History Working Papers” 54573, London School of Economics and Political Science, Department of Economic History, 2013.

${ }^{4}$ P. Malanima, The long decline of a leading economy: GDP in Central and Northern Italy, 1300-1913, EREH, t. 15, 2011, nr 2, s. 169-219; P. Malanima, When did England overtake Italy? Medieval and early modern divergence in prices and wages, EREH, t. 17, 2013, nr 1, s. 45-70; C. Álvarez-Nogal, L. Prados de la Escosura, The rise and fall of Spain (1270-1850), EHR, t. 66, 2013, nr 1, s. 1-37.

5 Ş. Pamuk, The Black Death and the origins of the 'Great Divergence' across Europe, 1300-1600, EREH, t. 11, 2007, nr 3, s. 289-317. 
ery nowożytnej, ale rozwarstwienie w Europie przybrało szczególnie na sile $\mathrm{w}$ ciagu XVII w. ${ }^{6} \mathrm{Z}$ tego punktu widzenia to ogólnoeuropejski kryzys gospodarczy XVII w., a nie czarna śmierć był momentem przełomowym $\mathrm{w}$ historii nierówności ekonomicznych wewnątrz kontynentu europejskiego. Po trzecie, badania porównawcze między północa a południem Europy oparte nie na płacach realnych, lecz na szacunkach dochodu narodowego brutto per capita sugeruja inny obraz wydarzeń. Według tej alternatywnej metody mierzenia materialnych standardów życia, w późnym średniowieczu kraje położone w rejonie Morza Śródziemnego, w szczególności północne Włochy, były bogatsze niż kraje północy. W początkach epoki nowożytnej doszło natomiast do zjawiska opisywanego $\mathrm{w}$ anglojęzycznej literaturze tematu, jako Reversal of Fortunes, kiedy to materialne standardy życia poprzednich liderów gospodarczych ulegały ciagłemu pogorszeniu, podczas gdy dochód narodowy brutto per capita w Anglii i Holandii sukcesywnie wzrastał $^{7}$. W konsekwencji, tak jak i w przypadku płac realnych, szacunki dochodu krajowego brutto per capita wykazały, że pod koniec epoki nowożytnej Anglia i Holandia, a nie Włochy, były najbogatszymi krajami Europy.

Zdecydowana większość międzynarodowych dyskusji dotyczących Little Divergence skupia się na porównaniu europejskiego południa i północy, przeoczając tym samym sytuację we wschodniej części kontynentu. Częściowo jest to wynik nieadekwatnego uczestnictwa badaczy zajmujących się Europą Wschodnią w międzynarodowych debatach toczących się na łamach wiodących czasopism naukowych poświęconych historii gospodarczej, takich jak: „European Review of Economic History”, „Economic History Review”, „Explorations in Economic History”, „Journal of Economic History” oraz „Cliometrica”. Nie znaczy to jednak, że ziemie polskie zostały w nich zupełnie zignorowane. Warto więc zapoznać się z dorobkiem badań nad materialnymi standardami życia w Pierwszej Rzeczypospolitej prowadzonych według metod wypracowanych w dotychczasowych dyskusjach. Celem tego artykułu jest systematyczne przedstawienie znanych szacunków płac realnych w miastach polskich oraz szacunków dochodu narodowego brutto per capita na ziemiach polskich w epoce przedrozbiorowej, naszkicowanie metodologii użytych w celu oszacowania tych wartości oraz omówienie i w miarę możliwości wyjaśnienie różnic pomiędzy szacunkami. Autor

${ }^{6}$ R. Allen, The Great Divergence in European wages and prices from the Middle Ages to the First World War, EEH, t. 38, 2001, nr 4, s. 411-447.

7 S. Broadberry, dz. cyt. 
nie rości sobie w tym miejscu pretensji do wyjaśnienie przyczyn, dla których doszło do rozejścia się dróg rozwojowych pomiędzy Wschodem a Zachodem Europy.

\section{Szacunki materialnych standardów życia w Pierwszej Rzeczypospolitej oparte na dziennych wynagrodzeniach miejskich robotników niewykwalifikowanych}

Jednym z najbardziej przejrzystych sposobów szacowania różnic pomiędzy materialnymi standardami życia w różnych gospodarkach używanym w międzynarodowej literaturze tematu jest porównanie wynagrodzeń robotników niewykwalifikowanych. Stanowią oni dogodna grupę dla badań porównawczych, ponieważ, jak sama nazwa wskazuje, ich wynagrodzenie nie było zależne od kwalifikacji. Oznacza to, że wysokość ich zarobków najprawdopodobniej była przede wszystkim zależna od podaży, popytu oraz ogólnej produktywności szeroko pojętej siły roboczej. Z kolei te czynniki zależały od ogólnego poziomu rozwoju gospodarki, a nie od kapitału ludzkiego i kwalifikacji indywidualnych robotników.

Większość opracowanych zarówno polskich, jak i zagranicznych źródeł notujących zarobki robotników niewykwalifikowanych w europejskich miastach w epoce nowożytnej opisuje dzienne wynagrodzenie osób pracujących w sektorze budowlanym wyrażone w lokalnej walucie. Rodzi to dwa poważne problemy metodologiczne związane z koniecznością porównania tych wartości pomiędzy krajami. Podstawowy problem dotyczy wartości samego pieniądza. Aby można było porównać wynagrodzenia wyrażone $\mathrm{w}$ różnych walutach, muszą one zostać sprowadzone do jakieś mniej lub bardziej abstrakcyjnej wspólnej wartości. Można to zrobić na dwa podstawowe sposoby. Po pierwsze, jeżeli znany jest kurs wymiany między walutami, płace mogą zostać zestandaryzowane poprzez przekonwertowanie ich na jedną walutę. Jednakże z powodu braku dokładnych danych dotyczących kosztów i kursu wymiany walut dla czasów nowożytnych, tego sposobu w praktyce nie używa się w badaniach historycznych. Po drugie, większość systemów monetarnych w epoce nowożytnej była oparta na monetach srebrnych lub złotych i zakładała pewien urzędowy kurs wymiany pomiędzy tymi kruszcami ${ }^{8}$. Monety były bite ze stopu jednego $\mathrm{z}$ tych metali szlachetnych z tańszym kruszcem. Z tego powodu wartość monety była

${ }^{8}$ Warto tu nadmienić, że ten urzędowy kurs wymiany między kruszcami był nagminnie różny od rynkowego. 
dwojakiego rodzaju, z jednej strony była to wartość urzędowa, a z drugiej - ze względu na użycie metali szlachetnych, zawierała ona wartość samą w sobie. Jeżeli arbitralnie założymy, że srebro albo złoto ma pewną uniwersalna wartość oraz że na rynku ludzie postrzegali wartość monety i wynagrodzenia płaconego w tej monecie tylko poprzez zawartość metali szlachetnych, a nie urzędową wartość monety, możemy wyrazić wynagrodzenia $\mathrm{w}$ różnych krajach w zarobionym kruszcu.

Podstawowym problemem przedstawionych dwóch metod porównawczych jest to, że ta sama miara wartości, dla przykładu gram srebra albo złota, może mieć inną siłę nabywczą w różnych gospodarkach. Ponadto metale szlachetne były towarem samym w sobie i na ich wartość wpływała między innymi podaż i popyt na te surowce. Z tego powodu płace przedstawia się $\mathrm{w}$ parytecie ich siły nabywczej. W historiografii obowiązuja dwie podstawowe metody tzw. urealnienia płac. Płace nominalne dzielone sa albo przez koszt takiej samej ilości tego samego dobra według cen lokalnych w różnych gospodarkach albo przez koszt całego koszyka różnych dóbr ${ }^{9}$.

Nim zaprezentujemy znane szacunki płac w Polsce na tle europejskim i przejdziemy do omówienia, jak użycie różnych metod zmienia obraz nierówności gospodarczych, warto omówić pozostałe problemy metodologiczne związane z użyciem płac realnych robotników niewykwalifikowanych jako miary standardów życia. Pierwszym z problemów jest fakt, że płace robotników niewykwalifikowanych reprezentuja zarobki jedynie małego procenta całkowitej populacji. Dane dotyczace płac w nowożytnej Europie zwyczaj dotycza wielkich ośrodków miejskich, które, ze względu na niski współczynnik urbanizacji kontynentu, reprezentuja jedynie margines całkowitej, głównie rolniczej, popula$\mathrm{cji}^{10}$. Z tego powodu porównanie płac realnych $\mathrm{w}$ miastach nie musi być reprezentatywne dla sektora rolniczego, w którym funkcjonowała zdecydowana większość populacji. Według badań przeprowadzonych przez Mikołaja Malinowskiego porównującego zarobki robotników niewykwalifikowanych w sektorach miejskim i wiejskim w Anglii, północnych Włoszech i Polsce (województwo krakowskie), zarobki pracowników niewykwalifikowanych w miastach były zawsze wyższe niż na wsi, a różnice w dochodach mieszkańców zachodnioeuropejskich miast i wsi były znacznie mniejsze niż w Europie Wschodniej ${ }^{11}$.

${ }^{9}$ W. Kula, Problemy i metody historii gospodarczej, Warszawa 1983.

10 P. Malanima, Pre-Modern European Economy, Leiden-Boston 2009.

${ }_{11}$ M. Malinowski, Little Divergence revisited: Polish weighted real wages in a European perspective, 1500-1800, EREH, t. 20, 2016, nr 3, s. 345-367. 
Obok owych różnic w dochodach między miastem a wsią problematyczne są również, wspomniane już, nierówności w dochodach wewnątrz miast, w szczególności pomiędzy robotnikami niewykwalifikowanymi a specjalistami. Procentowa różnica w zarobkach pomiędzy tymi dwiema grupami określana jest w anglojęzycznej literaturze tematu jako skill premium. Jan Luiten van Zanden porównał zarobki tych dwóch grup roboczych w wielu europejskich miastach i wykazał, że skill premium $\mathrm{w}$ miastach polskich, podobnie jak różnice między miastem a wsia przebadane przez Malinowskiego, były najwyższe na kontynencie europejskim ${ }^{12}$.

Trzecim problemem, jaki utrudnia użycie płac realnych jako miernika materialnych standardów życia, jest problem dostępności pracy. Jak już wspomniano, dostępne informacje na temat historycznych wynagrodzeń dotyczą zarobków dziennych, a nie rocznych. Studia porównawcze nad płacami realnymi albo wprost zakładaja, że wszyscy robotnicy w każdym kraju pracowali taką samą ilość czasu (najczęściej około 250 dni rocznie), albo pośrednio przyjmuja, że każdy robotnik mógł pracować, kiedy i ile chciał. Badacze krajów zachodnioeuropejskich starają się ustalić, jaka była przeciętna podaż siły roboczej mierzona liczbą przepracowanych dni, aby zastapić arbitralne założenia wiedzą historyczna. Problem ten powinien też zostać podjęty także w Polsce.

Od założeń teoretycznych i metodologicznych przejdźmy do omówienia obecnego stanu wiedzy dotyczącego materialnych standardów życia na ziemiach polskich, rozumianych tutaj jako ziemie wchodzące w skład tzw. Korony Królestwa Polskiego, w perspektywie europejskiej. Dostępne szacunki dotyczą sześciu miast: Gdańska, Warszawy, Krakowa, Lublina, Lwowa i Poznania. Płace i ceny użyte do oszacowania płac realnych w pięciu pierwszych miastach zostały opracowane i wydane w tzw. serii bujakowskiej ${ }^{13}$. Informacje dotyczace cen i płac

12 J.L. van Zanden, The skill-premium and the 'Great Divergence', EREH, t. 13, 2009, nr 1, s. 121-153.

${ }^{13}$ W. Adamczyk, Ceny w Lublinie, Lwów 1935; W. Adamczyk, Ceny w Warszawie w XVI i XVII wieku, Lwów 1938; F. Furtak, Ceny w Gdańsku w latach 1701-1815, Lwów 1938; S. Hoszowski, Ceny we Lwowie w XVI i XVII wieku, Lwów 1928; S. Hoszowski, Ceny we Lwowie $w$ latach 1701-1914, Lwów 1934; J. Pelc, Ceny w Krakowie $w$ latach 1369-1600, Lwów 1935; J. Pelc, Ceny w Gdańsku w XVI i XVII wieku, Lwów 1937; S. Siegel, Ceny $w$ Warszawie w latach 1701-1815, Lwów 1937; E. Tomaszewski, Ceny $w$ Krakowie $w$ latach 1601-1795, Lwów 1934. Omówienie źródeł i opracowania materiału źródłowego można znaleźć zarówno w rozdziałach otwierających odpowiednie publikacje wchodzace w skład serii, jak i w rozdziale XII klasycznej publikacji Witolda Kuli, Problemy i metody historii gospodarczej, Warszawa 1983. 
w Poznaniu zostały zaczerpnięte z opracowania Bogusława Więcławskiego i Mariana Mikego ${ }^{14}$. Poza tymi sześcioma miastami dysponujemy również opracowanymi cenami podstawowych produktów w Królewcu i Wrocławiu ${ }^{15}$. Niestety, brak opublikowanych zestawień dotyczących płac nominalnych w tych dwóch miastach nie pozwala uwzględnić ich w przekroju badawczym. Większość cen i płac została zebrana i zestandaryzowana przez Global Price and Income History Group ${ }^{16}$. Najwygodniejszym kompendium cen i płac w miastach polskich jest baza danych opracowana przez Roberta Allena ${ }^{17}$.

Szacunki płac robotników niewykwalifikowanych w nowożytnej Polsce zostały porównane $\mathrm{z}$ wiodacymi ośrodkami miejskimi $\mathrm{w}$ rejonie Mórz Północnego i Śródziemnego. Płace nominalne zostały wyrażone w srebrze, płace realne zaś - w ich sile nabywczej pszenicy i żyta oraz dwóch najpopularniejszych koszyków różnych dóbr używanych w literaturze tematu.

Płace nominalne wyrażone w srebrze od dawna były tematem badań porównawczych. Międzynarodowe dane dotyczące zarobków w różnych europejskich miastach $\mathrm{w}$ epoce przedprzemysłowej zostały zebrane i przeanalizowane przez wielu autorów ${ }^{18}$. Wśród nich był również Antoni Mączak, którego opracowanie płac w nowożytnej Europie znalazło jednak mały oddźwięk w międzynarodowej literaturze tematu' ${ }^{19}$.

Wykres 1 przedstawia dzienne wynagrodzenia niewykwalifikowanych robotników dniówkowych w Londynie, Amsterdamie, Madrycie, Mediolanie, Florencji, Warszawie, Gdańsku, Krakowie, Lwowie, Lublinie i Poznaniu. Dane dla pierwszych ośmiu miast zostały zaczerpnięte

${ }^{14}$ B. Więcławski, Zaopatrzenie i konsumpcja $w$ Poznaniu $w$ drugiej połowie XVIII wieku, Warszawa-Poznań 1989; „Global Price and Incomes History Group”, Prices and Wages in Poznań 1493-1600: http://gpih.ucdavis.edu, plik oparty na rękopisie opracowanym przez Mariana Mikego znajdującym się w Beveridge Box M15 w London School of Economics Archive.

${ }^{15}$ Ceny dla Królewca można znaleźć w tzw. Allen-Unger Global Commodity Prices Database (http://www.gcpdb.info/data.html); ceny dla Wrocławia można znaleźć na stronie Davida Jacksa (http://www.sfu.ca/ djacks/data/prices/Poland/index.html).

${ }^{16} \mathrm{http}: / / g p i h . u c d a v i s . e d u /$.

${ }_{17}$ R. Allen, dz. cyt.

18 Warto wymienić przynajmniej podstawowe publikacje, których autorzy przeprowadzili kompilacje interesujących nas danych: J.L. van Zanden, Wages and the standard of living in Europe, 1500-1800, EREH, t. 3, 1999, nr 2, s. 175-197; R. Allen, dz. cyt.; S. Broadberry, B. Gupta, The early modern great divergence: wages, prices and economic development in Europe and Asia, 1500-1800, EHR, t. 59, 2006, nr 1, s. 2-31.

19 A. Mączak, Development levels in early-modern Europe, w: tenże, Money, Prices and Power in Poland, Norfolk 1995. 
Wykres 1: Średnia nominalna wartość dziennego wynagrodzenia robotnika niewykwalifikowanego w wybranych miastach położonych na Północy, Południu i Wschodzie Europy wyrażona w gramach srebra

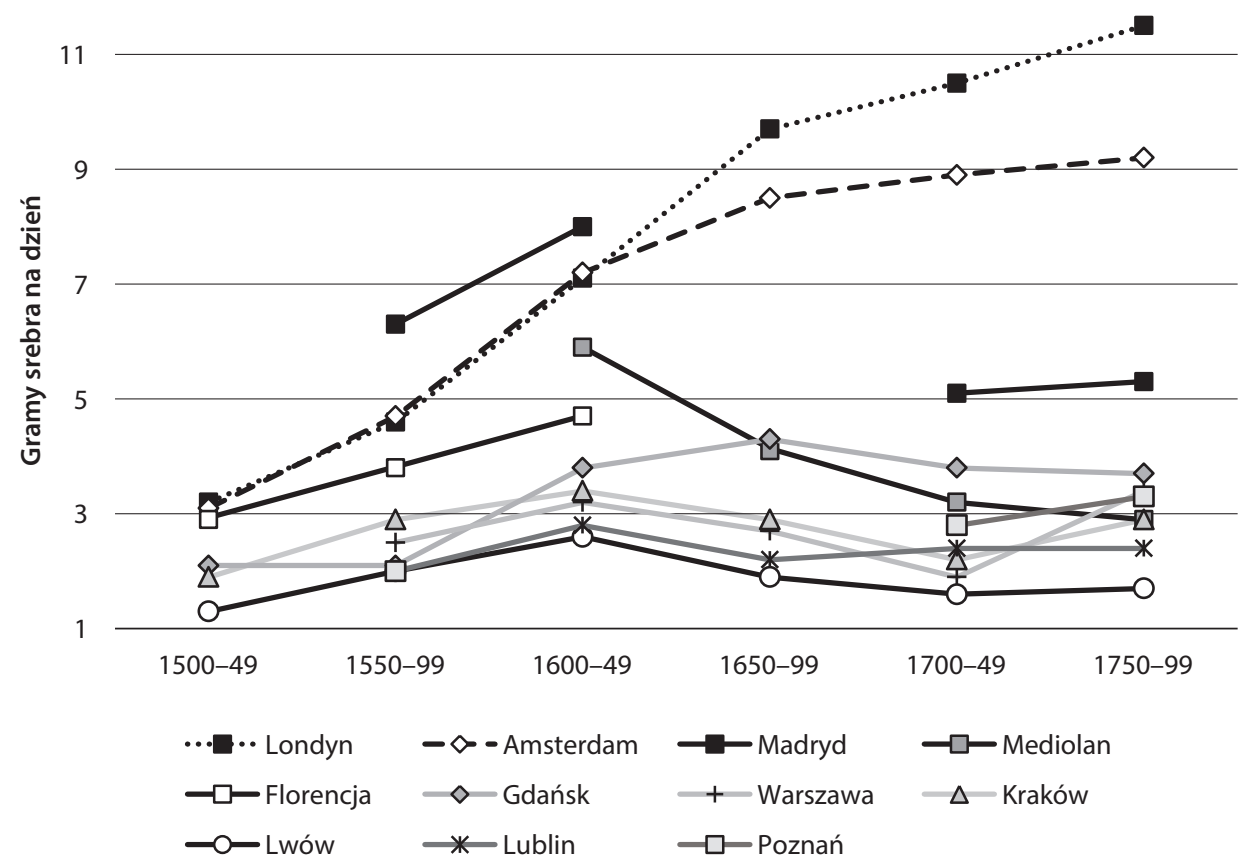

Źródło: S. Broadberry, B. Gupta, The early modern great divergence: wages, prices and economic development in Europe and Asia, 1500-1800, EHR, t. 59, 2006, nr 1, s. 2-31; M. Malinowski, Little Divergence revisited: Polish weighted real wages in a European perspective, 1500-1800, EREH, t. 20, 2016, nr 3, s. 345-367.

z badań Roberta Allena ${ }^{20}$. Dane dla Lwowa, Lublina i Poznania pochodzą z artykułu Mikołaja Malinowskiego ${ }^{21}$. Wykres jednoznacznie przedstawia, że od drugiej połowy XVII stulecia wynagrodzenia robotników niewykwalifikowanych były wyższe w Londynie i Amsterdamie niż w Europie Południowej i Wschodniej. W okresie wcześniejszym w miastach śródziemnomorskich były one relatywnie wysokie, ale ich poziom uległ jednak znacznemu obniżeniu w trakcie XVII w., podczas gdy płace w Amsterdamie i Londynie ciagle rosły. Wynagrodzenia w krajach zachodnich były wyższe niż w Królestwie Polskim już na początku ery nowożytnej, ale w wyniku załamania się materialnych standardów życia w Hiszpanii i we Włoszech płace nominalne wyrażone w srebrze na wschodzie i południu Europy były na podobnym poziomie. Wykres 1

\footnotetext{
${ }^{20}$ R. Allen, dz. cyt.

${ }^{21}$ M. Malinowski, dz. cyt.
} 
prezentuje również zróżnicowanie w dochodach w samej Polsce. Według płac nominalnych, Lwów był zdecydowanie miastem o najniższych wynagrodzeniach, a Gdańsk o najwyższych. Jedynie Kraków w drugiej połowie XVI w. odznaczał się wyższymi płacami nominalnymi. Analizując tylko dane przedstawione $\mathrm{w}$ wykresie 1, można przedwcześnie przyjaćc, że wiek XVI był okresem wzrostu materialnych standardów życia. Było to po części spowodowane rewolucją cen i spadkiem wartości srebra na kontynencie europejskim w wyniku importu tego kruszcu z Nowego Świata. W XVII w. doszło do spadku płac we wszystkich polskich miastach poza Gdańskiem, który obronił cechujacy to miasto, relatywnie stały poziom wynagrodzen. Spadek płac trwał aż do połowy XVIII w., kiedy to doszło do odwrócenia się trendu we większości polskich miast poza Lublinem i Lwowem, które utrzymały stały i relatywnie niski poziom płac nominalnych.

Sytuacja przedstawia się zupełnie inaczej jeżeli wyrazimy płace nominalne w parytecie ich siły nabywczej. Wykres 2 przedstawia średnią ilość litrów pszenicy albo żyta, jaka można było zakupić za wynagrodzenie za dzień pracy robotników niewykwalifikowanych w różnych europejskich miastach. Dane pochodza z badań przeprowadzonych przez Jana Luitena van Zandena ${ }^{22}$. Przedstawia ona tzw. grain wages robotników niewykwalifikowanych w Warszawie, Krakowie, Gdańsku, południowej Anglii, Florencji i Madrycie. Dane dla polskich miast oparte sa na cenach żyta, natomiast dane dla Anglii i Włoch - na pszenicy. Ponieważ zboże w Polsce, kraju słynącym z eksportu tego towaru, były znacznie tańsze niż w Europie Zachodniej, materialne standardy życia obserwowane ta metodą w Polsce są wyższe niż w Anglii i Włoszech. Jedynym wyjątkiem są wynagrodzenia w Gdańsku, które były na tym samym poziome, co w krajach Zachodu ze względu na wyższy poziom cen zboża w tym mieście, zbliżony, poprzez handel, do poziomu cen zachodnich ${ }^{23}$. Podczas gdy grain wages w Krakowie i Warszawie wykazywały trend zniżkowy, materialne standardy życia na Zachodzie i w Gdańsku utrzymywały się na relatywnie stałym poziomie.

Krokiem milowym w badaniach nad materialnymi standardami życia była metoda opracowana przez Roberta Allena, który zaproponował, aby wyrazić siłę nabywczą płac robotników nie przez wartość jednego produktu, ale przez koszt całego koszyka dóbr zwanego

22 J.L. van Zanden, Wages and the standard of living in Europe...

${ }_{23}$ D. Jacks, Market integration in the North and Baltic seas, 1500-1800, „Journal of European Economic History” 33, 2004, nr 3, s. 285-329. 
Wykres 2: Średnia ilość litrów zboża, jaka mogła być zakupiona za wartość jednej dniówki wypłaconej robotnikom niewykwalifikowanych w wybranych miastach/rejonach Europejskich

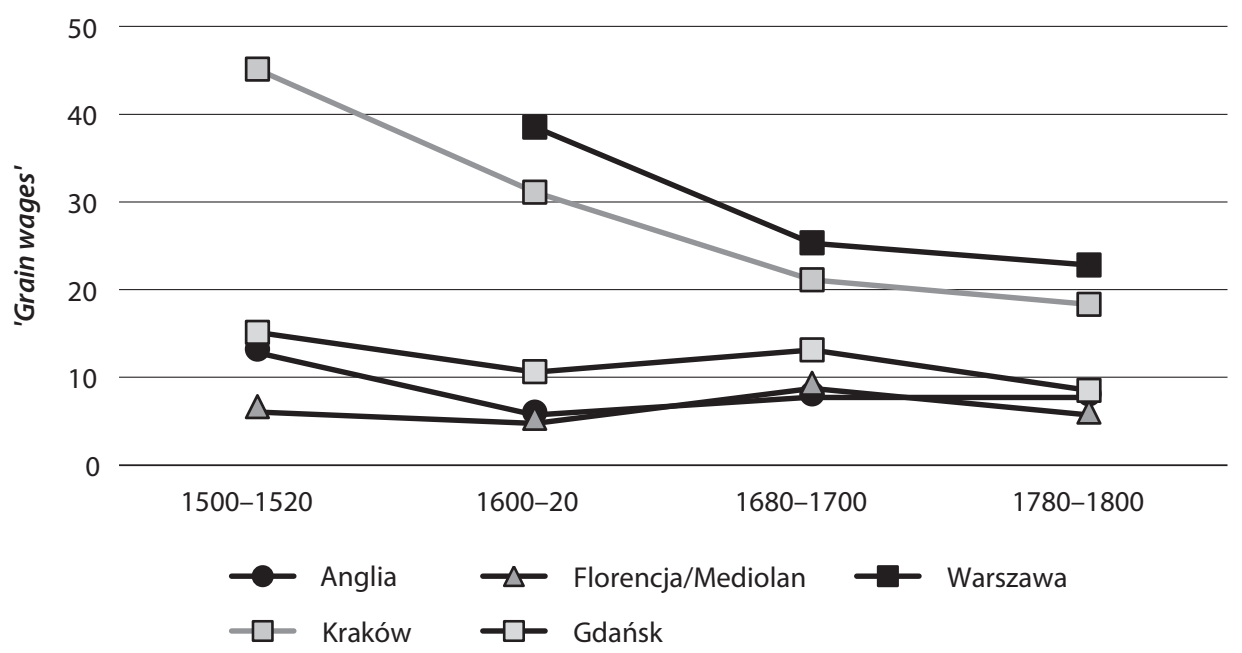

Źródło: J.L. van Zanden, Wages and the standard of living in Europe, 1500-1800, EREH, t. 3, 1999, nr 2, s. 175-197.

w literaturze tematu jako respectability basket ${ }^{24}$. W skład tego koszyka wchodzą stałe ilości chleba, grochu, mięsa, masła, sera, jaj, piwa, mydła, płótna, świec, oleju i opału. Zostały one tak dobrane, by dawały jednej osobie 1941 kilokalorii i 80 gram białka dziennie. Allen zaproponował, aby wyrażać siłę nabywczą nie kosztem jednego koszyka przeznaczonego dla jednej osoby na dzień, ale kosztem rocznej konsumpcji całego gospodarstwa domowego składającego się z dwóch osób dorosłych, w domyśle męża i żony, oraz dwojga dzieci. W przeciwieństwie do płac nominalnych wyrażonych w srebrze i grain wages, które skupiaja się na dochodzie za jeden dzień pracy, płace realne oszacowane przez Allena badaja przybliżone dochody roczne. Aby oszacować roczne dochody, mając jedynie dane dotyczące dniówek, Allen arbitralnie założył, że robotnicy dniówkowi w Europie pracowali 250 dni w roku oraz że ich płaca była jedynym dochodem ich gospodarstwa domowego. Po podzieleniu wartości trzech koszyków dóbr (dwóch koszyków dla osób dorosłych i jednego podzielonego między dwójkę dzieci) przez roczny dochód robotnika, otrzymuje się wartość znaną w literaturze jako welfare ratio. Miarę tę można interpretować jako wskaźnik wyrażajacy, ile standardowych

${ }^{24}$ R. Allen, dz. cyt. 
gospodarstw domowych mógł utrzymać za swoją płacę jeden robotnik niewykwalifikowany.

Należy tutaj nadmienić, że Allen ekstrapolował brakujące ceny chleba z informacji dotyczących cen zbóż i płac, gdyż nie znalazł żadnych informacji dotyczacych chleba w Polsce poza Krakowem. Z tego powodu większość informacji dotyczących tego podstawowego produktu, na których opieraja się szacunki Allena dla Polski, jest ahistoryczna i spekulatywna. Przykładowo, porównanie opracowanych przez Tadeusza Furtaka cen (pochodzących z taks wojewodzińskich regulujących ceny) chleba dla Gdańska w XVIII w. z cenami podanymi przez Allena sugeruje, że badacz ów mógł zaniżyć ceny chleba w tym mieście o 50 procent ${ }^{25}$.

Wykres 3: Średnie płace realne robotników niewykwalifikowanych w wybranych miastach europejskich wyrażone w welfare ratios

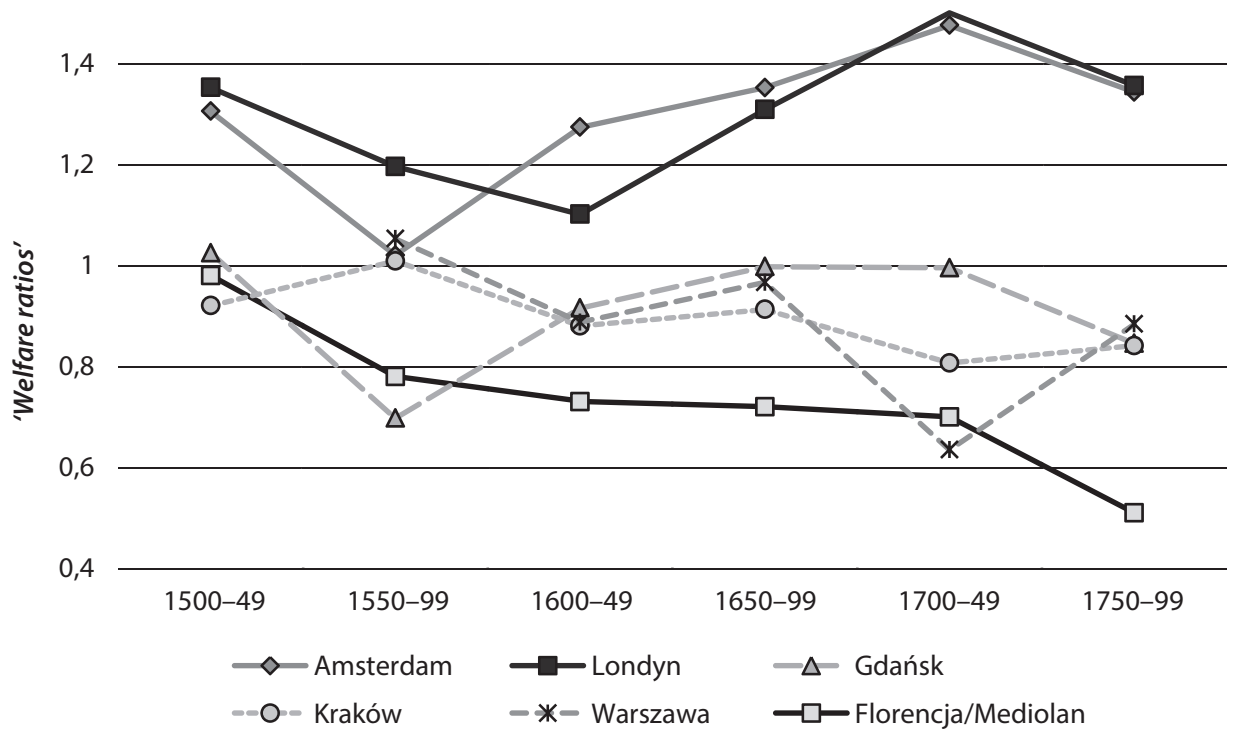

Źródło: R. Allen, The Great Divergence in European wages and prices from the Middle Ages to the First World War, EEH, t. 38, 2011, nr 4, s. 411-447.

Wykres 3 przedstawia obliczony przez Allena wskaźnik welfare ratios robotników niewykwalifikowanych w Amsterdamie, Londynie, Florencji/Mediolanie, Gdańsku, Krakowie i Warszawie ${ }^{26}$. Według niego już na początku ery nowożytnej główne miasta ulokowane w rejonie

\footnotetext{
25 A. Furtak, dz. cyt.

${ }^{26}$ R. Allen, dz. cyt.
} 
Morza Północnego odznaczały się wyższymi materialnymi standardami życia niż ośrodki znajdujące się w Europie Wschodniej i Południowej. W Polsce utrzymywały się na relatywnie stałym poziomie pomiędzy 1 i 0,8, zaś płace realne w Anglii i Holandii zaczęły sukcesywnie rosnąć od drugiej połowy XVII w. Jedynie płace realne w Gdańsku w drugiej połowie XVI w. i w Warszawie w pierwszej połowie XVIII w. uległy znacznemu zachwianiu. Zarazem wysokość płac realnych w północnych Włoszech spadała przez całą erę nowożytną z welfare ratio równego niemalże 1 do wartości około 0,5 .

W roku 2011 Allen wraz z całym zespołem współautorów zaproponował alternatywny koszyk dóbr użytych do mierzenia płac realnych ${ }^{27}$. Respectability basket zaproponowany 10 lat wcześniej miał z założenia, lepiej lub gorzej, przybliżać historyczną konsumpcję ludności. Ponieważ różnorodność modeli konsumpcji pomiędzy różnymi krajami i grupami społecznymi nie daje się ując jednym standardowym koszykiem dóbr, zaproponowano bardziej abstrakcyjny koszyk dóbr, znany jako bare-bones basket. Nie oddaje on realnej konsumpcji, ale najtańsze „minimum biologiczne”, jakie robotnik musiał zapewnić swojej rodzinie, aby mogli utrzymać się przy życiu. Bare-bones basket zakłada taką samą ilość kalorii i białka na osobę, co respectability basket, ale zamiast chleba i piwa zawiera zboże. Nie ma w nim także sera ani jaj. Koszyk ten zawiera również mniejsze liczby produktów konsumpcyjnych, takich jak płótno, świece czy mydło, oraz mniej opału. Według Allena i współautorów bare-bones basket, ze względu na swoja prostotę, nie tylko jest bardziej uniwersalny, ale także lepiej oddaje realia biedniejszych krajów (koszyk został stworzony, by badać sytuację w krajach azjatyckich i umożliwić ich porównanie z Europa Zachodnia). Metodologia użycia bare-bones basket jest taka sama, jak metodologia oparta na respectability basket. Płace realne oparte na bare-bones basket mierzy się $\mathrm{w}$ tzw. subsistence ratios.

Allen i współautorzy zmierzyli subsistence ratios oparte na bare-bones basket w Europie Zachodniej i Azji od XVIII do XX w. Subsistence ratios $\mathrm{w}$ polskich miastach, Florencji/Mediolanie i Londynie dla czasów nowożytnych zostały obliczone przez Mikołaja Malinowskiego ${ }^{28}$. Wykres 4 przedstawia międzynarodowe porównanie subsistence ratios z Polski, północnych Włoch i Anglii, przy czym uznano, że Londyn

${ }_{27}$ R. Allen, J. Bassino, D. Ma, C. Moll-Murata, J.L. Van Zanden, Wages, prices, and living standards in China, 1738-1925: in comparison with Europe, Japan, and India, EHR, t. 64, 2011, nr 1, s. 8-38.

${ }^{28}$ M. Malinowski, dz. cyt. 
odznaczał się najwyższym materialnym standardem życia w Anglii, a Florencja i Mediolan wiodły prym we Włoszech. Realne płace oparte na bare-bones basket ukazuja inny obraz niż w przypadku grain wages, sugerujących przewagę ekonomiczną Polski, oraz odmienną wizję niż $\mathrm{w}$ przypadku respectability basket, wskazujacych na dominację ekonomiczną Anglii. Według danych przedstawionych w wykresie 4, na początku ery nowożytnej najwyższe materialne standardy życia robotników niewykwalifikowanych w Anglii i Polsce były zbliżone. W drugiej połowie XVI i pierwszej połowie XVII w. płace realne w Londynie sukcesywnie spadały. Trend ten odwrócił się w drugiej połowie XVII w. Materialne standardy życia w Anglii w XVIII w. powróciły do poziomu z pierwszej połowy wieku XVI. Sytuacja w Polsce była całkiem inna. Podczas gdy materialne standardy życia w Anglii ulegały fluktuacji, najwyższe wartości w Polsce utrzymywały się na w miarę stałym poziomie. W wyniku tych trendów Polska i Anglia miały zbliżone materialne standardy życia (mowa tu o najwyższych wartościach dla każdego kraju) około połowy wieku XVI i w XVIII stuleciu. Natomiast około XVII w. Anglia mogła być biedniejsza. Wykres 4 również przedstawia sytuację w północnych Włoszech. Płace realne wyrażone $\mathrm{w}$ subsistence ratios $\mathrm{w}$ rejonie śródziemnomorskim mogły być niższe niż w innych rejonach Europy już na początku ery nowożytnej. W wyniku regresji gospodarczej tego rejonu zróżnicowanie dochodów miedzy północnymi Włochami a resztą kontynentu znacznie się pogłębiło do końca ery nowożytnej.

Wykres 4 przedstawia tylko średnią maksymalnych płac realnych z kilku polskich miast. $\mathrm{Z}$ kolei wykres 5 prezentuje oszacowane przez M. Malinowskiego płace realne oparte na bare-bones basket dla Gdańska, Warszawy, Karkowa, Lublina, Poznania i Lwowa ${ }^{29}$. Dane te sugerują narastające zróżnicowanie pomiędzy miastami mającymi dostęp do Wisły lub Warty, to jest Gdańskiem, Krakowem, Warszawą i Poznaniem, a Lublinem i Lwowem znajdującymi się poza główną siecia rzeczna. Zróżnicowanie $\mathrm{w}$ materialnych poziomach życia między tymi typami miast nasiliło się w pierwszej połowie XVII w. W XVI w. materialne standardy życia robotników niewykwalifikowanych we Lwowie i Lublinie były zbliżone do gdańskich, natomiast od drugiej ćwierci XVII w. aż do końca badanego okresu płace realne w miastach bez dostępu do większych rzek były najniższe w kraju. Miasta ulokowane nad rzekami dzieliły mniej lub bardziej podobne trendy zmian w poziomie standardów życia. Robotnicy niewykwalifikowani we wszystkich

29 Tamże. 
Wykres 4: Średnie płace realne robotników niewykwalifikowanych w Londynie, Północnych Włoszech i najbogatszych polskich miastach wyrażone $\mathrm{w}$ subsistence ratios

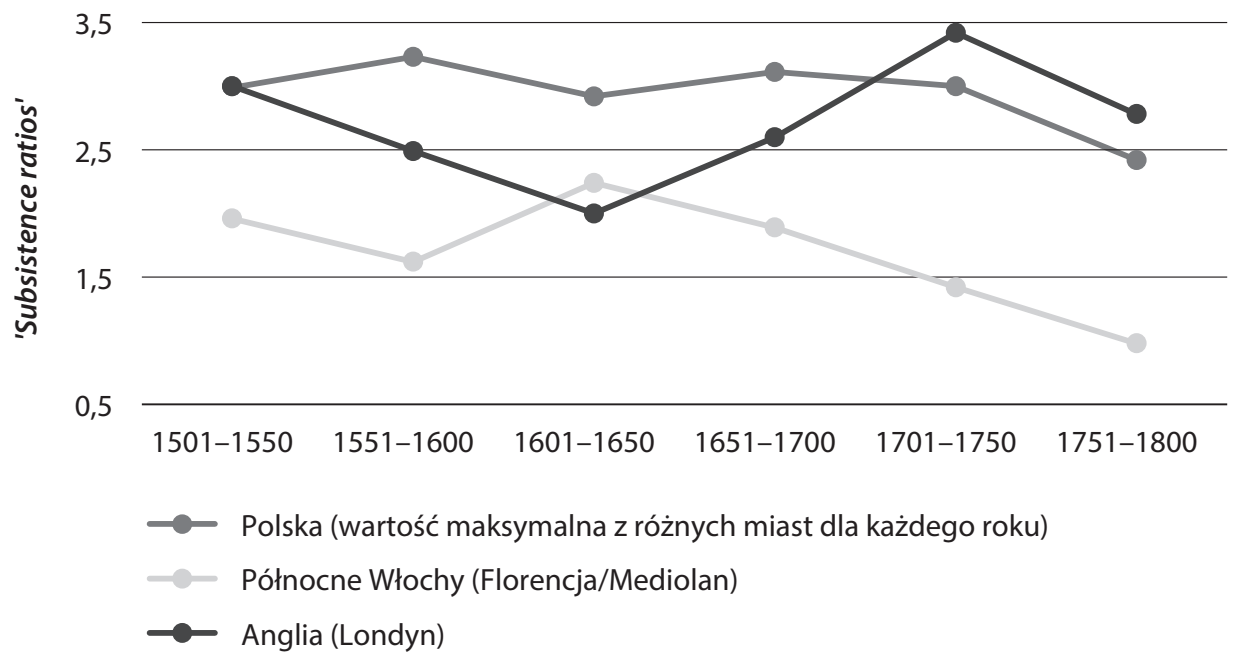

Źródło: M. Malinowski, Little Divergence revisited...

Wykres 5: Średnie płace realne robotników niewykwalifikowanych w Polskich miastach wyrażone w subsistence ratios

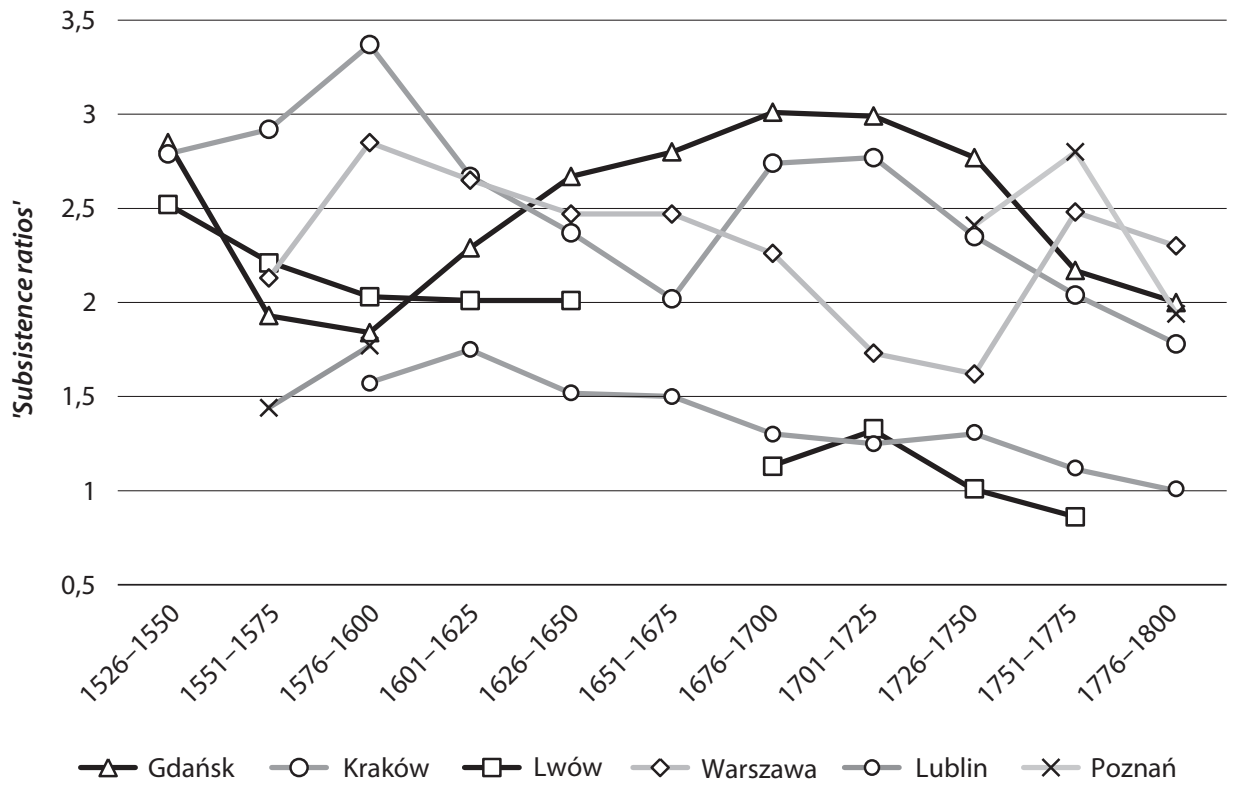

Źródło: M. Malinowski, Little Divergence revisited... 
miastach, dla których są oszacowane wartości dla pierwszej połowy XVI w. (to jest Kraków, Gdańsk i Lwów) były relatywnie bogate. W drugiej połowie tego stulecia doszło do krótkiego rozejścia się standardów życia w miastach położonych nad Wisła, płace realne w Krakowie i Warszawie wzrosły w tym czasie, natomiast materialne warunki życia w Gdańsku uległy pogorszeniu. W pierwszej połowie XVII stulecia doszło do konwergencji standardów życia w miastach ulokowanych nad Wisła na poziomie z pierwszej połowy XVI w. Materialne standardy życia robotników niewykwalifikowanych w tych miastach utrzymały się na relatywnie wysokim poziomie do drugiej połowy XVIII w., kiedy to uległy pogorszeniu. Jedynym wyjątkiem była Warszawa, która podupadła gospodarczo w ostatniej ćwierci XVII i pierwszej połowie XVIII w. Materialne standardy życia w stolicy uległy jednak polepszeniu w drugiej połowie XVIII w., gdy zrównały się z płacami realnymi w Gdańsku, Krakowie i Poznaniu.

Porównanie nominalnych płac robotników niewykwalifikowanych wyrażonych $\mathrm{w}$ srebrze $\mathrm{z}$ ich płacami realnymi wyrażonymi w ich sile nabywczej zboża lub dwóch rożnych koszyków dóbr ukazuje, że uzyskany obraz nierówności gospodarczych zależy od użytej metodologii. W skrócie płace nominalne wyrażone w srebrze wskazują jednoznacznie na prymat gospodarczy miast położonych w rejonie Morza Północnego. Z kolei obraz, jaki prezentuja płace realne, zależy od udziału zboża w koszyku użytym do mierzenia ich siły nabywczej. Według grain wages opartych tylko na zbożu, robotnicy mieszkający w miastach polskich, poza Gdańskiem, byli najbogatsi w Europie. Z kolei welfare ratios, które zamiast zboża uwzględniaja jego produkty pochodne, takie jak chleb i piwo, sugeruja, że Europa Wschodnia była biedniejsza od Zachodniej. Subsistance ratios, które zawierają zarówno zboże (zamiast chleba i piwa), jak i produkty rzemiosła, sugeruje z kolei, że Anglia i Polska mogły mieć podobne materialne standardy życia.

Różnice pomiędzy płacami nominalnymi wyrażonymi w srebrze a grain wages zostały już w po części wyjaśnione przez Stephena Broadberry'ego i Bishnupriyę Guptę ${ }^{30}$. Badacze ci twierdza, że różnice $\mathrm{w}$ pomiarach są wynikiem tzw. efektu Balassy-Samuelsona, według którego cena produktów niehandlowych (takich jak zboże, które jest znacznie trudniejsze w transporcie niż produkty rzemiosła) jest odwrotnie proporcjonalna do produktywności siły roboczej w sektorze niehandlowym i wprost proporcjonalna do produktywności siły roboczej w sektorze handlowym. Nominalne płace miały być wyższe w obszarze

\footnotetext{
${ }^{30}$ S. Broadberry, B. Gupta, dz. cyt.
} 
Wykres 6: Zmiany w ilorazie płacy realnej robotnika niewykwalifikowanego w Londynie i wybranych Polskich miastach wynikające ze zmian w składzie koszyka dóbr

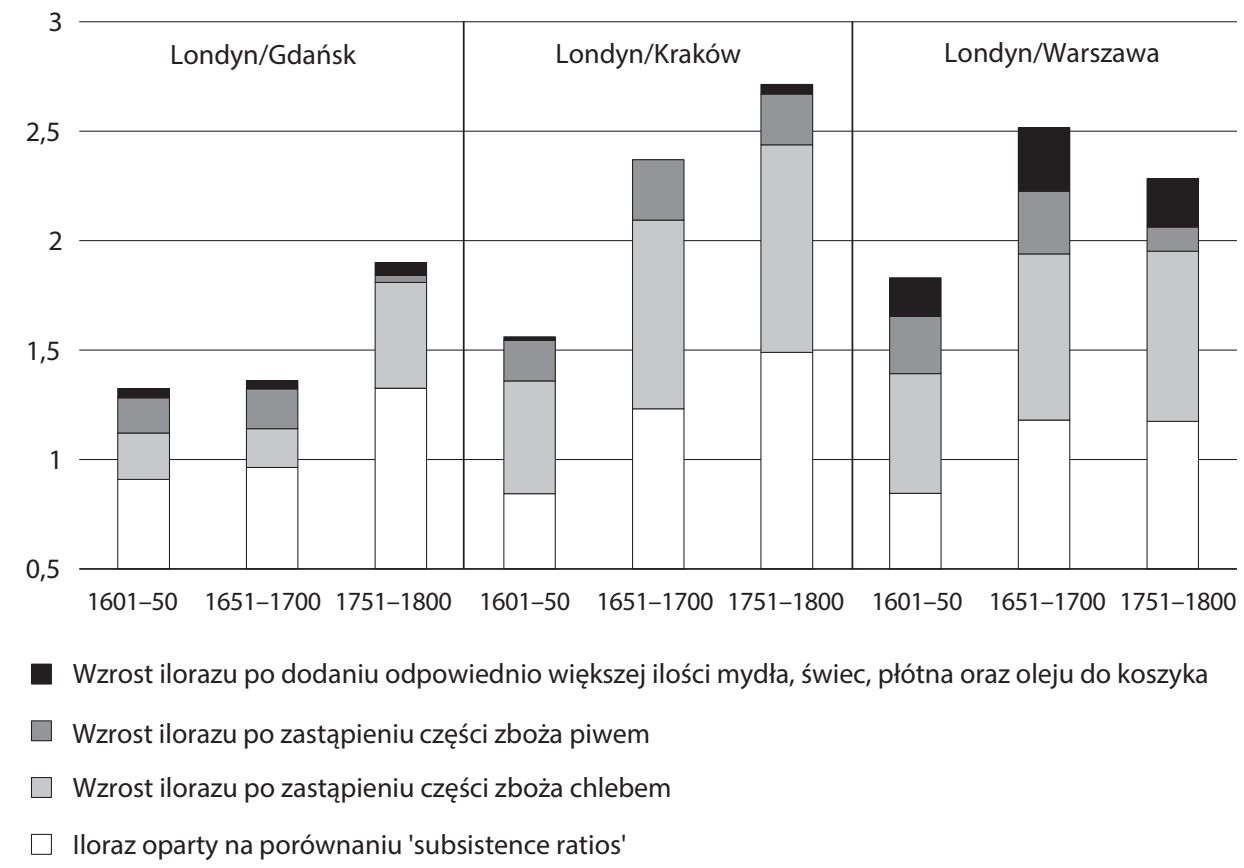

Źródło: M. Malinowski, Little Divergence revisited...

Morza Północnego ze względu na większe znaczenie sektora handlowego $\mathrm{w}$ tamtym rejonie gospodarczym, który sprzyjał produktywności siły roboczej w sektorze handlowym, a co za tym idzie i zwyżce cen produktów niehandlowych (zboże). Z kolei niski poziom rozwoju sektora handlowego w Polsce miał być powodem nie tylko relatywnie niskich płac, ale również i niskich cen artykułów niehandlowych (w tym zboża).

Wykres 6 prezentuje, jak zmiany w kompozycji koszyka wpływaja na obraz nierówności pomiędzy polskimi miastami a Londynem. Biała kolumna ukazuje wynik dzielenia subsistence ratio w Londynie poprzez subsistence ratio $\mathrm{w}$ danym polskim mieście. Wartości większe od 1 oznaczaja, że materialne standardy życia w Londynie były wyższe, a mniejsze od 1 - że niższe niż w porównywanym polskim mieście. W miarę zastępowania zboża wchodzącego w skład koszyka przez chleb i piwo, dysproporcja między Polską a Anglią zwiększa się na korzyść Anglii. Ta zmiana wynika $\mathrm{z}$ faktu, że relatywna cena chleba i piwa w Polsce w stosunku do ceny zboża była znacznie wyższa niż w krajach bardziej rozwiniętych ekonomicznie. Sugeruje to, że zarówno produktywność w sektorze piekarskim i piwnym, jak i ogólne koszty przetwórstwa zbożowego 
były wyższe w Polsce niż w Anglii. Mogło to być spowodowane, m.in. niskim poziomem urbanizacji, wysokim kosztem wykwalifikowanej siły roboczej (sugerowanym przez wspomniane już wysokie skill premium w Polsce zidentyfikowane przez van Zandena), drożyzną kapitału oraz polityka ekonomiczna szlacheckiej Rzeczypospolitej: handel i produkcja zboża w Polsce była stosunkowo nisko opodatkowana, natomiast budżet państwa w znacznej części utrzymywał się z podatków na alkohol, takich jak składne winne, kolekta piwna, szelężne oraz akcyza ${ }^{31}$.

\section{Szacunki materialnych standardów życia w Pierwszej Rzeczypospolitej oparte na produkcie krajowym brutto per capita}

Produkt krajowy brutto (PKB) wyraża wartość wszystkich dóbr i usług finalnych wytworzonych na terenie danego kraju w ciagu jednego roku. Jest to jedna z podstawowych miar dochodu narodowego. PKB podzielony przez liczbę mieszkańców (PKB per capita) oddaje średnią wartość gospodarki przypadająca na jednego mieszkańca. Po przyjęciu szeregu arbitralnych założeń, takich jak brak importu/eksportu i tezauryzacji, PKB można zrównać z dochodem narodowym brutto i konsumpcja narodowa. PKB per capita oddaje zatem średni dochód i konsumpcję na mieszkańca i uchodzi często za najodpowiedniejszą miarę materialnych standardów życia ludności. Największym mankamentem tej metody szacunkowej jest występujące w rzeczywistości nierównomierne rozłożenie dochodu pomiędzy mieszkańcami. W przeciwieństwie do płac realnych oddających sytuację jakiejś rzeczywistej grupy ludności (np. robotników niewykwalifikowanych), PKB per capita opisuje abstrakcyjnego i ahistorycznego „uśrednionego" mieszkańca, który nie musi być reprezentatywny dla większości populacji, w szczególności gdy mamy do czynienia ze znacznymi rozbieżnościami $\mathrm{w}$ dochodach $\mathrm{w}$ gospodarce. Ważnym elementem krytyki jest również nieuwzględnienie w PKB wartości czasu wolnego oraz pominięcie produkcji autarkicznej gospodarstw domowych. Te problemy sprawiaja, że PKB nie jest idealnym narzędziem do mierzenia gospodarki opartej na produkcji folwarczno-pańszczyźnianej.

31 Według danych dotyczących dochodów skarbu zebranych przez Rybarskiego, w drugiej połowie XVII w. dochód państwa z tych podatków mógł wynieść średnio nawet $25 \%$ wszystkich prowentów ordynaryjnych; zob. R. Rybarski, Skarb i pieniadza za Jana Kazimierza, Michała Korybuta i Jana III, Warszawa 1939. 
Szeroko zakrojone międzynarodowe badania porównawcze nad historycznymi szacunkami PKB dla różnych krajów zostały rozpoczęte przez Angusa Maddisona w latach dziewięćdziesiątych XX w. ${ }^{32}$ Jego inicjatywa badawcza zainspirowała wielu uczonych, którzy starają się albo poprawić, często wielce spekulacyjne, już istniejące szacunki, albo oszacować wartości PKB dla uprzednio nieprzebadanych krajów. Niewątpliwie warta wspomnienia międzynarodową grupa badająca obecnie historyczne PKB jest tzw. Maddison Project. Została ona nazwana tak na cześć zmarłego już badacza, a działa pod kierunkiem Jana Luitena van Zandena. Najważniejszą edycją najnowszych badań nad historycznym PKB jest tzw. Maddison Update, opracowany przez Juttę Bolt i van Zandena, opublikowany w „Economic History Review” w 2014 r. ${ }^{33}$

W warunkach idealnych PKB liczy się poprzez przeliczenie cen artykułów finalnych w różnych sektorach przez ich całkowitą produkcję. Dla czasów nowożytnych zrekonstruowano PKB oparte na relatywnie dokładnych danych dotyczacych woluminu produkcji tylko dla Anglii i Holandii. Najnowsze szacunki dla innych krajów europejskich (Niemcy, Włochy, Hiszpania, Polska) opierają się na mniej wiarygodnej, uproszczonej metodologii „na skróty”, czyli tzw. short-hand method albo short-cut method, która zostanie omówiona poniżej ${ }^{34}$.

PKB per capita i płace realne moga sugerować inne trendy w materialnych standardach życia. Według Luisa Angelesa różnica w trendach ma miejsce, jeżeli w czasie obserwacji następuje zmiana jednej z trzech wartości: (a) dystrybucji dochodu w populacji, (b) podaży siły roboczej albo (c) relacji między cenami towarów konsumpcyjnych produkowanych $\mathrm{w}$ różnych sektorach ${ }^{35}$. Warto więc obie miary, czyli PKB per capita i płace realne, ze sobą porównywać.

W latach sześćdziesiątych Jerzy Topolski i Andrzej Wyczański przeprowadzili wstępne badania nad woluminem produkcji rzemieślniczej (żelazo) i rolniczej w Polsce ${ }^{36}$. Jednakże nie przetłumaczyli oni

32 A. Maddison, Contours of the World Economy 1-2030 AD: Essays in MacroEconomic History, Oxford 2007.

${ }^{33}$ J. Bolt, J.L. van Zanden, dz. cyt.

${ }^{34}$ U. Pfister, „Economic growth in Germany, 1500-1850”, artykuł zaprezentowany na konferencji Quantifying Long Run Economic Development, Wenecja, 22-24 III 2011; C. Alvarez-Nogal, L. Prados de la Escosura, dz. cyt.; P. Malanima, The long decline...

${ }^{35}$ L. Angeles, GDP per capita or real wages? Making sense of conflicting views on pre-industrial Europe, EEH, t. 45, 2008, nr 2, s. 147-163.

36 J. Topolski, Wskaźniki wzrostu gospodarczego Polski od X do XX wieku, „Kwartalnik Historyczny" 74, 1967, s. 995-1012; J. Topolski, A. Wyczanski, Les fluctuations de la production agricole en Pologne XVI $-X V I I I^{e}$ siècles, w: Prestations paysannes, dîmes, 
otrzymanych wartości na szacunki PKB (zrobił to dopiero Van Zanden, co zostanie omówione w dalszej części tego artykułu). Pierwsza próba oszacowania PKB w Polsce były badania Wyczańskiego ${ }^{37}$. Autor ten zrekonstruował wartość dochodu narodowego dla roku 1580, ale nie porównał wyników z podobnymi szacunkami dla Anglii i Holandii. Nie uczestniczył on tym samym w Little Divergence Debate avant la lettre. Mimo to wkład Wyczańskiego w rozwój historiografii nie powinien być pominięty, a jego metoda pozwala na opracowanie szacunków dla innych lat i może być wykorzystywana przez kolejne pokolenia badaczy.

Wyczański oparł swoje szacunki dochodu narodowego na badaniach nad konsumpcją żywności w Polsce. Przemnożył on ustaloną przez siebie typową konsumpcję ludności przez jej liczebność, by oszacować jej całkowita produkcję. Następnie użył cen gdańskich, aby oszacować wartość tej produkcji. Ponieważ PKB oblicza się na podstawie dóbr finalnych, odją on wartość wyprodukowanych półproduktów (na przykład wartość zbóż użytych do produkcji piwa lub chleba). Ze względu na brak danych dotyczacych woluminu produkcji rzemieślniczej w sektorze miejskim Wyczański założył, że wartość tej produkcji na mieszkańca sektora miejskiego była równa wartości typowej konsumpcji opartej na szacunkach dotyczących sektora rolnego. W ten sposób, zapewne niepoprawnie, zrównał standardy życia na wsi i w mieście, tym samym zakładając, że produktywność ludności w tych sektorach była podobna, co kłóci się z przyjętą powszechnie opinią o nowożytnych miastach jako motorach postępu i wzrostu produktywności ${ }^{38}$. Wyczański również nie był w stanie oszacować woluminu produkcji leśnej, przez co postanowił usunąć ją ze swoich szacunków. Dokładną krytykę metody Wyczańskiego przeprowadzili Marcin Kamler i Antoni Maczak ${ }^{39}$.

Pierwsze przybliżone obliczenia PKB dla Polski, osadzone w kontekście Little Divergence, zostały dokonane przez van Zandena ${ }^{40}$. Autor użył szacunków produkcji zbożowej w Polsce opracowanych przez Topolskiego i Wyczańskiego, i połączył je z informacjami dotyczącymi urbanizacji ${ }^{41}$.

rente foncière et mouvement de la production agricole à l'époque préindustrielle, red. J. Goy, E. Le Roy Ladurie, t. 1, Paris 1982.

${ }^{37}$ A. Wyczański, Studia nad konsumpcja żywności $w$ Polsce w XVI $i$ w pierwszej połowie XVII w., Warszawa 1969.

${ }_{38}$ P. Malanima, Pre-Modern European Economy...

${ }^{39}$ M. Kamler, A. Mączak, Spożycie i dochód narodowy, „Przegląd Historyczny” 62, 1971, s. $112-120$.

${ }^{40}$ J.L. van Zanden, Early-modern economic growth: a survey of the European economy, 1500-1800, w: Early-Modern Capitalism, Economic and Social Change in Europe 1400-1800, red. M. Prak, London 2001.

${ }^{41}$ J. Topolski, A. Wyczański, dz. cyt. 
Aby oszacować PKB per capita w Polsce, van Zanden dokonał czterech podstawowych operacji. Po pierwsze, założył, że w roku 1820 PKB w Polsce równało się $46 \%$ PKB brytyjskiego. Wartości te zostały zaczerpnięta z rachunków PKB zebranych przez Angusa Maddisona dla tego roku ${ }^{42}$. Po drugie, Van Zanden arbitralnie założył, że produkcja przemysłowa i wartość usług w tym roku stanowiły pomiędzy $20 \%$ a $33 \%$ gospodarki, a produkcja rolna odpowiednio pomiędzy $80 \%$ a $67 \%$. W ten sposób van Zanden obliczył relatywną wartość tych sektorów gospodarczych wyrażonych jako część brytyjskiej gospodarki w roku 1820. Po trzecie, aby obliczyć relatywna wartość produkcji rolnej w dawnej Polsce, autor połączył zindeksowane szacunki woluminu produkcji oszacowane przez Topolskiego i Wyczańskiego z relatywną wielkością sektora rolnego w roku 1820. Po czwarte, aby określić względna wielkość sektora przemysłowego i sektora usług, autor połaczył zindeksowane szacunki urbanizacji w Polsce, oparte na danych zaproponowanych przez Jana de Vries, z relatywną wielkością tych sektorów w $1820 \mathrm{r.}^{43}$

Wykres 7: Produkt krajowy brutto per capita w dawnej Polsce w porównaniu z innymi krajami europejskimi wg ustaleń Jana Luitena van Zandena, wyrażony jako procent PKB per capita Wielkiej Brytanii w 1820 r.

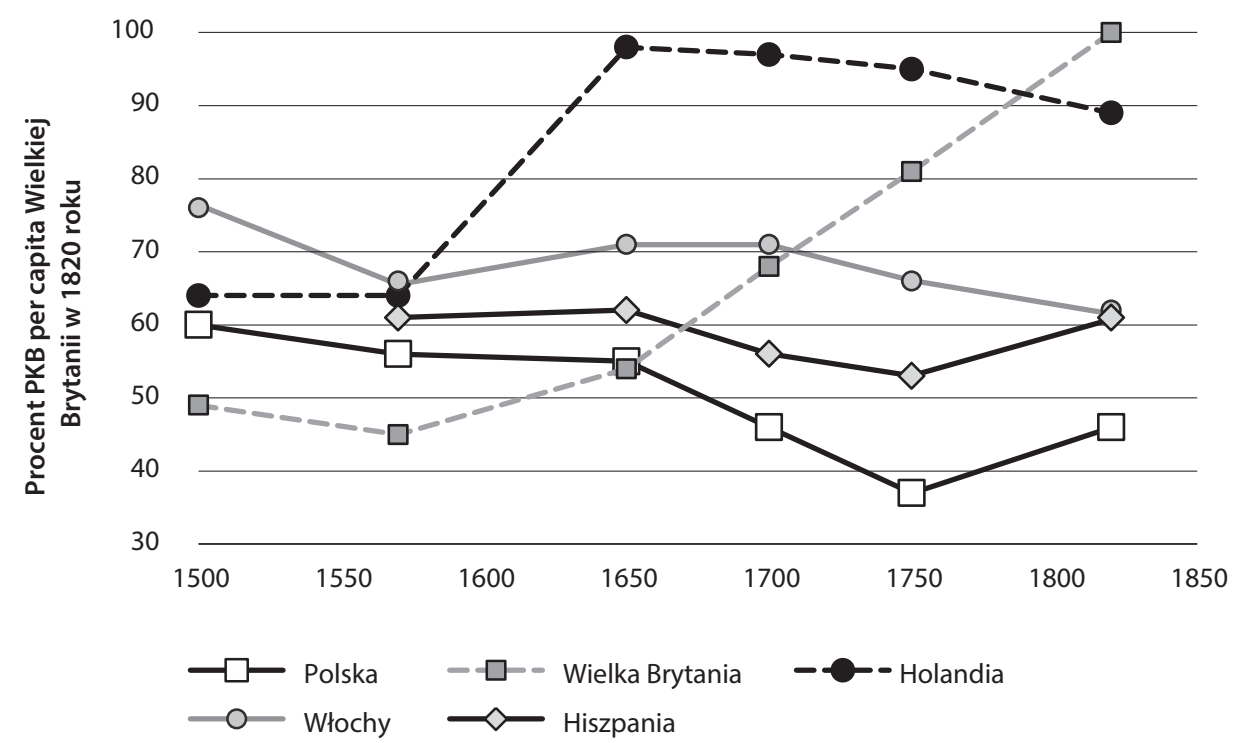

Źródło: J.L. van Zanden, Early-modern economic growth: a survey of the European economy, 15001800, w: Early-Modern Capitalism, Economic and Social Change in Europe 1400-1800, ed. M. Prak, Londyn 2001.

42 A. Maddison, Monitoring the World Economy, 1820-1992, Paris 1995.

43 J. De Vries, European Urbanization, 1500-1800, Boston 1984. 
Wykres 7 przedstawia wykonane przez van Zandena porównanie szacunków dochodu narodowego w Polsce, Wielkiej Brytanii, Holandii, Hiszpanii oraz Włoszech, zakładających wysoki udział sektorów produkcyjnego i usług w gospodarce ${ }^{44}$. Dane sugeruja, że Polska na początku ery nowożytnej nie była dużo biedniejsza od innych europejskich krajów, jednakże w wyniku regresu ekonomicznego w drugiej połowie XVII i pierwszej połowie XVIII w. stała się najbiedniejszym z badanych państw. Szacunki zaprezentowane przez van Zandena sugeruja, że na początku ery nowożytnej regionem cechującym się najwyższymi materialnymi standardami życia były Włochy, ale w XVII wieku doszło do wzrostu gospodarczego w Holandii, który stała się najbogatszym państwem europejskim. Prymat gospodarczy tego kraju utrzymał się przez całą erę nowożytna. Anglia wyprzedziła Holandię dopiero po rewolucji przemysłowej pod koniec XVIII w.

Van Zanden wyraził PKB w dawnej Polsce jako część PKB Anglii w 1820 r. Pierwszym badaczem, który wyraził PKB w dawnej Polsce w pieniądzu był Grzegorz Wójtowicz. Autor ten przedstawił PKB na ziemiach polskich w dolarach amerykańskich z 2007 r. Badania Wójtowicza opublikowane w 2009 r., oparte na wcześniejszych ustaleniach z 2006 r., sa zdecydowanie najsłabsze metodologicznie i warsztatowo ze wszystkich rekonstrukcji PKB w Polsce ${ }^{45}$. Wójtowicz w swojej książce z 2006 r. nie wyjaśnia wcale albo wyjaśnień tych nie eksponuje wystarczająco, skąd pochodzą użyte przez niego wartości, a zamiast przybliżyć czytelnikowi użytą przez siebie metodologię, deklaruje jedynie, że wszystkie jego dane oparte sa o „szacunki i obliczenia własne”.

Wójtowicz zrekonstruował PKB per capita w nowożytnej Polsce i zestawił te obliczenia ze średnim PKB dla krajów Europy Zachodniej, aby wykazać zacofanie gospodarcze Europy Wschodniej. W przeciwieństwie do większości badaczy, którzy dla oszacowania wartości PKB używają danych dotyczących płac, konsumpcji albo woluminu produkcji, Wójtowicz oszacował wartość produkcji, używając standardowej w ekonomii rozwoju funkcji produkcji Cobba-Douglasa, która przedstawia się następująco:

$$
Y=A * L^{a} * H^{b} * K^{c} * N^{d}
$$

Gdzie $Y$ wyraża PKB, $L$ - wkład pracy, $H$ - wkład kapitału ludzkiego, $K$ - wkład kapitału fizycznego, $N$ - zasoby naturalne, $a-d-$

\footnotetext{
${ }^{44}$ J.L. van Zanden, Early-modern economic growth...

45 G. Wójtowicz, A. Wójtowicz, Dlaczego nie jesteśmy bogaci?, Warszawa 2009.
} 
różne odpowiednie parametry, zaś $A$ - produktywność. Wójtowicz enigmatycznie wyjaśnia, że użyte parametry sa „wynikiem subiektywnego wyboru na podstawie przeprowadzonych [bliziej niesprecyzowanych] badań empirycznych". Roczny czas pacy $L$ został oszacowany przez Wójtowicza poprzez przemnożenie całkowitej pracującej populacji (arbitralnie założono, że to $40 \%$ całej populacji) poprzez 60 godzin na tydzień (również arbitralne założenie). Kapitał ludzki $H$ został przybliżony poprzez przeciętne wykształcenie pracujących. Autor wyjaśnia proweniencje tych danych, enigmatycznie pisząc „dla okresu dawnej Polski przyjęto wyniki hipotetycznych obliczeń”. Kapitał fizyczny $K$, znany również kapitałem trwałym, uwzględnia wytworzone wcześniej i używane w czasie produkcji środki produkcji, jak narzędzia lub środki transportu. Pochodzenie szacunków kapitału trwałego użytego przez Wójtowicza nie zostało w pełni wyjaśnione. Natomiast złoża naturalne $N$ zostały przybliżone przez Wójtowicza przez całkowite terytorium kraju. Aby przeskalować obliczenia i wyrazić wynik w dolarach autor wyraził produktywność $A$ jako wydajność pracy na godzinę w tej walucie, ale nie wyjaśnił dokładnie, w jaki sposób obliczył wartości $A$.

Wykres 8: Produkt krajowy brutto per capita w Polsce i Europie Zachodniej wg ustaleń Wójtowicza wyrażony w dolarach amerykańskich wg ich siły nabywczej w 2007 r.

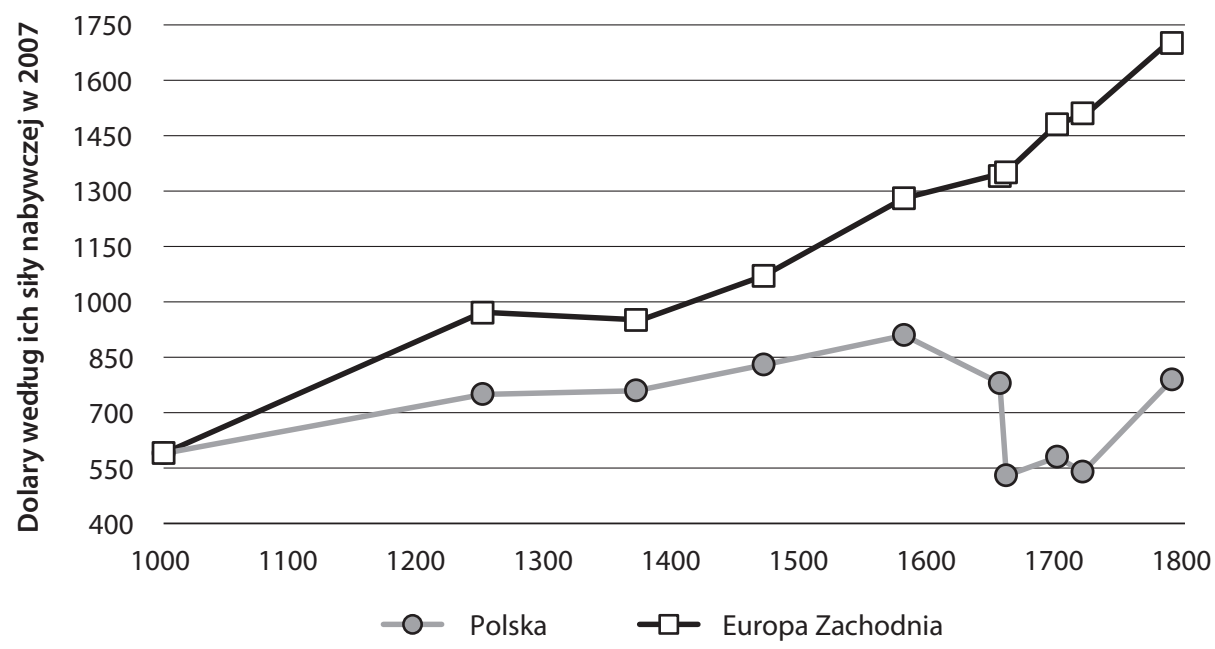

Źródło: G. Wójtowicz, A. Wójtowicz, Dlaczego nie jesteśmy bogaci?, Warszawa 2009.

Wykres 8 przedstawiający wyniki ustaleń Wójtowicza sugeruje ogólny trend wzrostowy od początku państwowości polskiej aż do roku 1580 oraz regres gospodarczy, który rozpoczął się w pierwszej połowie 
wieku XVII i przybrał na sile po wojnach połowy XVII stulecia. Od kryzysu drugiej połowy XVII w. do pierwszej połowy XVIII w. miała miejsce stagnacja gospodarcza. Według szacunków Wójtowicza doszło w Polsce do odbudowy gospodarczej w drugiej połowie XVIII w., ale W stopniu niewystarczajacym, by osiagnąc ponownie poziom materialnych standardów życia z wieku XVI. Wójtowicz zestawił swoje szacunki PKB per capita na ziemiach polskich ze średnimi szacunkami dla państw zachodnioeuropejskich. Według jego ustaleń Europa Zachodnia była bogatsza od Polski już w XIII w. Rozwarstwienie narosło w trakcie epoki nowożytnej szczególnie w wyniku regresu gospodarczego w Polsce, który nie miał miejsca na szeroko pojętym Zachodzie. Warto w tym miejscu zauważyć, że szacunki polskiego badacza oparte sa na nieaktualnych już danych dotyczących PKB per capita w Anglii i Holandii. Nowe szacunki PKB sugeruja, że materialne standardy życia były wyższe niż uprzednio zakładano, przez co rozwarstwienie obserwowane metodą Wójtowicza było zapewne jeszcze głębsze.

Najnowszego oszacowania PKB per capita dla ziem polskich dokonali Mikołaj Malinowski i Jan Luiten van Zanden ${ }^{46}$. W przeciwieństwie do poprzednich ustaleń, badacze zaproponowali wartości tylko dla województwa krakowskiego, a nie dla całego kraju. Swoje ustalenia oparli oni na obecnie najpopularniejszej metodzie mierzenia PKB, znanej w żargonie jako short-hand method albo short-cut method, która wykorzystano do najnowszych obliczeń PKB dla nowożytnych Włoch, Niemiec i Hiszpanii. Dzięki temu ustalenia Malinowskiego i van Zandena nadają się do międzynarodowych badań porównawczych. Metodologia w gruncie rzeczy jest podobna do tej użytej przez van Zandena w 2001 r., ale bynajmniej nie identyczna. Zakłada ona, że istnieja znane szacunki PKB dla tzw. roku bazowego oraz że wiadomo, jaki procent całkowitej produkcji w tym roku został wytworzony w sektorze rolnym. Następnie zakłada się, że istnieją pewne stałe relacje między rozmiarem populacji, urbanizacja (industrializacja), cenami, płacami realnymi a PKB. Dzięki tym stałym relacjom odtworzonym poprzez analizę roku bazowego można odtworzyć szacunki PKB per capita dla lat innych niż rok bazowy, jeżeli znane są dla tych lat płace realne, współczynnik urbanizacji i wielkość populacji.

Pierwszym krokiem w całym szeregu obliczeń wchodzących w skład oszacowania PKB jest obliczenie stałej relacji pomiędzy płacami realnymi a wartością całkowitej produkcji/konsumpcji żywności poprzez

${ }^{46}$ M. Malinowski, J.L. van Zanden, National income and its distribution in preindustrial Poland in a global perspective, „Cliometrica” 11, 2017. 
identyfikację tej relacji dla roku bazowego. Następnie używa się danych dotyczących płac realnych (Malinowski i van Zanden oparli się na szacunkach Malinowskiego dla Krakowa ${ }^{47}$ ), aby oszacować wartość całkowitej produkcji/konsumpcji żywności dla innych lat. Podobnie oblicza się stałą relację pomiędzy udziałem sektora rolnego a udziałem ludności pracującej w sektorze rolnym (Malinowski i van Zanden oparli się na szacunkach Malinowskiego dla województwa krakowskiego ${ }^{48}$ ). Ostatnim krokiem jest użycie szacunków dotyczących wartości produkcji rolnej, populacji i współczynnika urbanizacji, aby obliczyć całkowite $\mathrm{PKB}^{49}$.

Nowatorstwo prac tych badaczy polegało na tym, że zamiast opierać się na szacunkach Maddisona z XIX w., stworzyli oni własną rekonstrukcje PKB dla drugiej połowy XVI w. Malinowski i van Zanden posłużyli się danymi dotyczącymi dochodów populacji, a nie jej konsumpcji, jak to sugerował Wyczański (ani obliczonej niebezpośrednio produkcji, jak zaproponował Wójtowicz). Badacze, w oparciu o wcześniejsze szacunki dochodów i obliczenia demografów historycznych, zaproponowali średni dochód 14 różnych grup ludności (od żebraka do króla). Mnożąc średni dochód przez populację każdej kategorii oraz sumując otrzymane wyniki, uzyskali oni szacunek PKB dla jednego punktu w czasie, który był ich rokiem bazowym. Dokładny opis wszystkich założeń i decyzji podjętych przez badaczy oraz pochodzenie użytych przez nich danych przedstawili w swoim artykule. Warto może nadmienić tutaj jedynie, że Malinowski i van Zanden w znacznym stopniu bazowali na dorobku innych badaczy, jak na przykład Jan Rutkowski $^{50}$ (dla obliczenia dochodu szlachty i króla z folwarków i miast), Piotr Guzowski ${ }^{51}$ (dla obliczenia budżetów gospodarstw chłopskich), Julian Pelc $^{52}$ (dla obliczenia wynagrodzeń ludności miejskiej i rzemieślników) oraz Anna Izydorczyk-Kamler (dla obliczenia wynagrodzeń robotników folwarcznych $)^{53}$.

Wykres 9 przedstawia PKB per capita w Holandii, Anglii, Północnych Włoszech, Hiszpanii i Polsce reprezentowanej przez województwo

\footnotetext{
${ }^{47}$ M. Malinowski, Little Divergence...

${ }^{48}$ Tamże.

${ }^{49}$ M. Malinowski, J.L. van Zanden, dz. cyt.

${ }^{50}$ J. Rutkowski, Badania nad podziatem dochodów $w$ Polsce $w$ czasach nowożytnych, Kraków 1938.

${ }^{51}$ P. Guzowski, Chłopi i pieniqdze na przełomie średniowiecza i czasów nowożytnych, Kraków 2008.

52 J. Pelc, Ceny w Krakowie...

${ }^{53}$ A. Izydorczyk-Kamler, Wynagrodzenie pracowników najemnych w folwarkach małopolskich w XVI i pierwszej połowie XVII wieku, „Przegląd Historyczny” 81, 1990, s. $655-667$.
} 
Wykres 9: Produkt krajowy brutto per capita w województwie krakowskim w porównaniu z różnymi krajami europejskimi według ustaleń Mikołaja Malinowskiego i Jana Luitena van Zandena wyrażony w dolarach amerykańskich wg ich siły nabywczej w $1990 \mathrm{r}$.

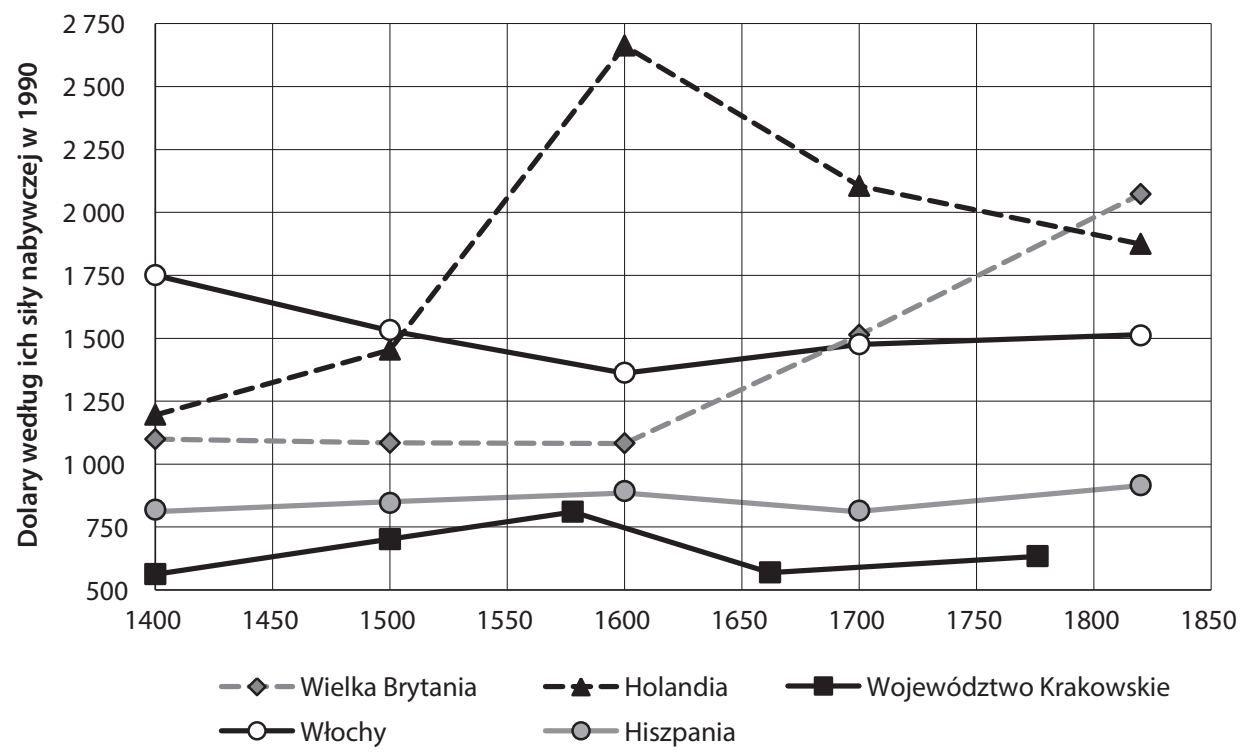

Źródło: M. Malinowski, J.L. van Zanden, National income and its distribution in preindustrial Poland in a global perspective, „Cliometrica” 11, 2017.

krakowskie. Wszystkie wartości zostały oddane w dolarach amerykańskich w parytecie ich siły nabywczej z 1990 r. Jest to najpopularniejsza $\mathrm{w}$ literaturze tematu miara historycznych PKB rozpropagowana przez Maddisona i znana również jako międzynarodowe dolary Geary'ego-Khamisa. Według szacunków zaproponowanych przez Malinowskiego i van Zandena (podobnie jak w szacunkach Wójtowicza, ale odmiennie niż w szacunkach van Zandena z 2001 r.) materialne standardy życia w Polsce rosły przez wieki XV i XVI. PKB per capita spadało drastycznie od końca XVI w. aż do okresu po wojnach połowy XVII w. Według szacunku PKB per capita w 1776 r., XVIII stulecie było okresem bardziej stagnacji niż odbudowy gospodarczej. Mogło być to spowodowane albo postępującym upadkiem gospodarczym Galicji, albo tym, że odbudowa gospodarcza XVIII w. (zidentyfikowana przez Wójtowicza i van Zandena) nabrała impetu dopiero po Sejmie Czteroletnim. Podobnie jak w poprzednich dwóch szacunkach PKB, materialne standardy życia w Polsce były niższe niż w Europie Zachodniej, szczególnie po kryzysie wieku XVII. Warto powtórzyć, że różnice pomiędzy Wschodnią i Zachodnią Europa są większe niż w poprzednich badaniach, 
ponieważ wykres 9 prezentuje najnowsze i poprawione szacunki dla Anglii i Holandii ${ }^{54}$.

Omówione cztery różne szacunki PKB w nowożytnej Polsce opracowano przy użyciu różnych metod badawczych i oparto na różnych typach źródeł. Z tego powodu nie da się w prosty sposób wyjaśnić, jakie są bezpośrednie przyczyny wyżej wymienionych różnic pomiędzy szacunkami, jak dało się to zrobić w przypadku łatwiejszych do obliczenia i porównania płac realnych. Mimo różnic w trendach pomiędzy szacunkami, warto zwrócić uwagę, że wszystkie wyniki sugeruja, iż druga połowa XVII i pierwsza XVIII w. były okresami najniższych materialnych standardów życia w Rzeczypospolitej oraz że materialne standardy życia w Polsce przedrozbiorowej były niższe niż w Europie Zachodniej już przed rewolucją przemysłowa.

\section{Podsumowanie}

Zaprezentowane wyżej szacunki PKB per capita oraz płac robotników niewykwalifikowanych w polskich miastach w epoce nowożytnej zostały zestawione z odpowiednimi szacunkami dla Europy Północno-Zachodniej i Południowej. Porównanie różnych wyników badań płac realnych wykazało, że im bardziej koszyk dóbr użytych do urealniania płac opiera się na nieprzetworzonym zbożu, tym relatywnie wyższe stają się wynagrodzenia polskich robotników. Znaczący wpływ na uzyskany obraz zróżnicowania w dochodach wewnątrz kontynentu europejskiego ma użyta w badaniach metodologia. Na tym etapie badań nie da się jednoznacznie określić, która z metod obliczania płac realnych jest najtrafniejsza, ale zadaniem historyka gospodarczego jest raczej identyfikacja różnic pomiędzy szacunkami, w celu wyjaśnienia i zrozumienia ich pochodzenia wynikającego z odmienności badanych gospodarek.

W przeciwieństwie do różnych szacunków płac realnych, które nie prezentuja jasnego obrazu zróżnicowania gospodarczego na kontynencie europejskim, różne szacunki PKB per capita dla dawnej Polski jednoznaczne sugeruja, że kraj ten był zacofany gospodarczo w porównaniu z Europą Zachodnią już w okresie nowożytnym, a w szczególności w XVIII w. Wszystkie opisane szacunki PKB sa jednak jedynie

${ }_{54}$ J.L. van Zanden, B. van Leeuwen, Persistent but not consistent: The growth of national income in Holland 1347-1807, EEH, t. 49, s. 119-130; S. Broadberry, S. Campbell, A. Klein, M. Overton, B. Van Leeuwen, British Economic Growth, 1270-1870, Cambridge 2015. 
przybliżeniem rzeczywistych historycznych wartości produktu narodowego, który winien być obliczony z (jeszcze nieopracowanych) danych dotyczących produkcji. Nowe ustalenia Adama Izdebskiego i współautorów dotyczące trendów w produkcji rolnej na części ziem polskich $\mathrm{w}$ epoce nowożytnej opracowane na podstawie danych palynologicznych (pyłki na dnie jezior) sa obiecującym krokiem w kierunku poprawy istniejących szacunków PKB $^{55}$. Niestety, brak nowych badań nad woluminem produkcji rzemieślniczej w Polsce, wykraczających poza szacunkowe ustalenia Jerzego Topolskiego dotyczące produkcji żelaza, ogranicza rozwój wiedzy nad historycznym $\mathrm{PKB}^{56}$. Badania podstawowe nad woluminem produkcji przemysłowej winny być więc kolejnym celem dla historyków gospodarczych zajmujących się materialnymi standardami życia w dawnej Polsce i ogólnym wzrostem gospodarczym dawnej Rzeczypospolitej.

\section{Bibliografia}

Abel W., Agricultural fluctuations in Europe. From the thirteenth to twentieth centuries, London-New York 1980.

Adamczyk W., Ceny w Lublinie. Lwów 1935

Adamczyk W., Ceny w Warszawie w XVI i XVII wieku, Lwów 1938.

Allen R., Bassino J., Ma D., Moll-Murata C., Van Zanden J.L., Wages, prices, and living standards in China, 1738-1925: in comparison with Europe, Japan, and India, „Economic History Review” 64, 2011, nr 1, s. 8-38.

Allen R., The Great Divergence in European wages and prices from the Middle Ages to the First World War, „Explorations in Economic History” 38, 2001, nr 4, s. 411-447.

Álvarez-Nogal C., Prados de la Escosura L., The rise and fall of Spain (12701850), „Economic History Review” 66, 2013, nr 1, s. 1-37.

Angeles L., GDP per capita or real wages? Making sense of conflicting views on pre-industrial Europe, „Explorations in Economic History” 45, 2008, nr 2, s. 147-163.

Bolt J., Van Zanden J.L., The Maddison Project: collaborative research on historical national accounts, „Economic History Review” 67, 2014, nr 3, s. $627-651$.

Broadberry S., Accounting for the great divergence, „Economic History Working Papers" 54573, London School of Economics and Political Science, Department of Economic History, 2013.

55 A. Izdebski, G. Koloch, T. Słoczyński, M. Tycner-Wolicka, On the use of palynological data in economic history: new methods and application to agricultural output in central Europe, EEH, t. 59, s. 17-39.

${ }^{56}$ J. Topolski, dz. cyt. 
Broadberry S., Gupta B., The early modern great divergence: wages, prices and economic development in Europe and Asia, 1500-1800, „Economic History Review" 59, 2006, nr 1, s. 2-31.

De Vries J., European Urbanization, 1500-1800, Boston 1984.

Guzowski P., Chłopi i pieniadze na przełomie średniowiecza i czasów nowożytnych, Kraków 2008.

Hoszowski S., Ceny we Lwowie w latach 1701-1914, Lwów 1934.

Hoszowski S., Ceny we Lwowie w XVI i XVII wieku, Lwów 1928.

Izdebski A., Koloch G., Słoczyński T., Tycner-Wolicka M., On the use of palynological data in economic history: new methods and application to agricultural output in Central Europe, „Explorations in Economic History” 59, s. $17-39$.

Izydorczyk-Kamler A., Wynagrodzenie pracowników najemnych w folwarkach małopolskich w XVI i pierwszej połowie XVII wieku, „Przegląd Historyczny" 81, 1990, s. 655-667.

Jacks D., Market integration in the North and Baltic seas, 1500-1800, „Journal of European Economic History" 33, 2004, nr 3, s. 285-329.

Kamler M., Mączak A., Spożycie i dochód narodowy, „Przegląd Historyczny” 62,1971 , s. $112-120$.

Koepke N., Baten J., The biological standard of living in Europe during the last two millennia, „European Review of Economic History” 9, 2005, nr 1, s. 61-95.

Kula W., Problemy $i$ metody historii gospodarczej, Warszawa 1983.

Maddison A., Contours of the World Economy 1-2030 AD: Essays in MacroEconomic History, Oxford 2007.

Maddison A., Monitoring the World Economy, 1820-1992, Paris 1995.

Malanima P., Pre-Modern European Economy, Leiden-Boston 2009.

Malanima P., The long decline of a leading economy: GDP in Central and Northern Italy, 1300-1913, „European Review of Economic History” 15, 2011, nr 2, s. 169-219.

Malanima P., When did England overtake Italy? Medieval and early modern divergence in prices and wages, „European Review of Economic History” 17, 2013, nr 1, s. 45-70.

Malinowski M., Little Divergence revisited: Polish weighted real wages in a European perspective, 1500-1800, „European Review of Economic History" 20, 2016, nr 3, s. 345-367.

Malinowski M., Van Zanden J.L., National income and its distribution in preindustrial Poland in a global perspective, „Cliometrica” 11, 2017.

Mączak A., Development levels in early-modern Europe, w: A. Mączak, Money, Prices and Power in Poland, Norfolk 1995.

Pamuk Ş., The Black Death and the origins of the 'Great Divergence' across Europe, 1300-1600, „European Review of Economic History” 11, 2007, nr 3, s. 289-317.

Pelc J., Ceny w Gdańsku w XVI i XVII wieku, Lwów 1937.

Pelc J., Ceny w Krakowie w latach 1369-1600, Lwów 1935. 
Pfister U., „Economic growth in Germany, 1500-1850”, artykuł zaprezentowany na konferencji Quantifying Long Run Economic Development, Wenecja, 22-24 III 2011.

Rutkowski J., Badania nad podziałem dochodów w Polsce w czasach nowożytnych, Kraków 1938.

Rybarski R., Skarb i pieniadza za Jana Kazimierza, Michata Korybuta i Jana III, Warszawa 1939.

Siegel S., Ceny w Warszawie w latach 1701-1815, Lwów 1937.

Tomaszewski E., Ceny w Krakowie w latach 1601-1795, Lwów 1934.

Topolski J., Wskaźniki wzrostu gospodarczego Polski od X do XX wieku, „Kwartalnik Historyczny” 74, 1967, s. 995-1012.

Topolski J., Wyczanski A., Les fluctuations de la production agricole en Pologne $X V I^{e}-X V I I I{ }^{e}$ siècles, w: Prestations paysannes, dîmes, rente foncière et mouvement de la production agricole à l'époque préindustrielle, ed. J. Goy, E. Le Roy Ladurie, t. 1, Paris 1982.

Van Zanden J.L., Early-modern economic growth: a survey of the European economy, 1500-1800, w: Early-Modern Capitalism, Economic and Social Change in Europe 1400-1800, ed. M. Prak, London 2001.

Van Zanden J.L., The 'Revolt of Early Modernists' and the 'first modern economy': an assessment, „Economic History Review” 55, 2002, nr 4, s. 619-641.

Van Zanden J.L., The skill-premium and the 'Great Divergence', „European Review of Economic History" 13, 2009, nr 1, s. 121-153.

Van Zanden, Wages and the standard of living in Europe, 1500-1800, „European Review of Economic History" 3, 1999, nr 2, s. 175-197.

Więcławski B., Zaopatrzenie i konsumpcja w Poznaniu $w$ drugiej połowie XVIII wieku, Warszawa-Poznań 1989.

Wójtowicz G., Wójtowicz A., Dlaczego nie jesteśmy bogaci?, Warszawa 2009.

Wyczański A., Studia nad konsumpcja żywności w Polsce w XVI $i$ w pierwszej połowie XVII w., Warszawa 1969.

Mikołaj Malinowski

Measuring backwardness. Comparison of the most important estimates of material standards of living in pre-industrial Poland (Summary)

The text provides a comprehensive summary of known accounts of nominal wages represented in silver, grain wages, and real wages. It compares estimates for Poland with corresponding ones for the North Sea region and the Mediterranean. It shows that choice of methodology greatly influences the perceived income dissimilarity between East and West of the European Continent. In particular, the more processed grains (beer and bread) feature in a basket used to deflate the wages, the higher the perceived economic superiority of England over Poland. Conversely, if we deflate the nominal wages 
only by prices of unprocessed grains, Poland appears to have been the richest country in early modern Europe. The text also describes the known accounts of gross domestic product per capita in Poland. The summary of the estimates indicates that, in spite of the fact that all the known reconstructions are based on different data and methodologies, all the accounts suggest that Poland was much poorer than Western European counties at least already in the $18^{\text {th }}$ century.

Mikołaj Malinowski - dr, historyk gospodarczy specjalizujacy się w badaniach nad rozwojem gospodarczym Europy Środkowo-Wschodniej z zastosowaniem metod ilościowych; w badaniach stara się ustalić, kiedy i dlaczego doszło do rozejścia się dróg rozwojowych różnych części kontynentu europejskiego. Jest inicjatorem WEast, czyli międzynarodowej grupy badaczy zajmujacych się historia gospodarcza regionu. Obecnie pracuje na Wydziale Historii Gospodarczej Uniwersytetu w Lund jako postdoctoral research fellow. E-mail: mikolaj.malinowski@ekh.lu.se. 